\title{
Ultrasonic assisted extraction to obtain bioactive, antioxidant and antimicrobial compounds from marcela
}

\section{Caroline Pagnossim Boeira ${ }^{1^{*}} \odot$ Natiéli Piovesan $^{2}$ Marcela Bromberger Soquetta ${ }^{3}$ Déborah Cristina Barcelos Flores ${ }^{1}$ Bruna Nichelle Lucas $^{1}$ Juliano Smanioto Barin ${ }^{1}$ Claudia Severo da Rosa ${ }^{1}$ Nelcindo Nascimento Terra ${ }^{1}$}

${ }^{1}$ Programa de Pós-graduação em Ciência e Tecnologia dos Alimentos, Universidade Federal de Santa Maria (UFSM), 97105.900, Santa Maria, RS, Brasil. E-mail: carolinepagnossim@hotmail.com. *Corresponding author. ${ }^{2}$ Instituto Federal do Rio Grande do Norte (IFRN), Pau dos Ferros, RN, Brasil.

${ }^{3}$ Programa de Pós-graduação em Engenharia Química, Universidade Federal de Santa Maria (UFSM), Santa Maria, RS, Brasil.

\begin{abstract}
The aim of this study was to evaluate the effect of extraction conditions on bioactive compounds, as well as on antioxidant activity, and the antimicrobial activity of the extracts with the highest antioxidant characteristics. The extracts were obtained by conventional method and ultrasound-assisted extraction at various temperatures $\left(20^{\circ} \mathrm{C}, 40^{\circ} \mathrm{C}\right.$ and $\left.60^{\circ} \mathrm{C}\right)$. Total phenolics, total flavonoids, antimicrobial activity and antioxidant activity were quantified by the methods of DPPH, FRAP, and ORAC, respectively. The conventional extraction method and ultrasound method influenced the phenolic content at all the tested temperatures. Flavonoids were not influenced by extraction methods. The antioxidant activity (DPPH) was highest in the ultrasonic method at temperatures of $40^{\circ} \mathrm{C}$ and $60^{\circ} \mathrm{C}$; however, in the case of the FRAP method the best results were for the conventional extraction method. The conventional and ultrasonic methods did not influence the IC $C_{50}$ at temperatures of $20^{\circ} \mathrm{C}$ and $40^{\circ} \mathrm{C}$, but using ORAC the antioxidant activity was influenced by the methods at all temperatures. The extract obtained at $60^{\circ} \mathrm{C}$ by the ultrasound method had high antimicrobial action in relation to the strains of Salmonella sp., Escherichia coli, and Staphylococcus aureus. Extraction ultrasonic-assisted can be considered adequate to obtain extracts of marcela, which are rich in bioactive compounds with high antioxidant activity.
\end{abstract}

Key words: ultrasound, bioactive compounds, natural antioxidant, Achyrocline satureioides.

Extração assistida por ultrassom para obtenção de compostos bioativos, antioxidantes e antimicrobianos de marcela

RESUMO: O objetivo deste trabalho foi avaliar o efeito das condições de extração sobre os compostos bioativos, bem como sobre a atividade antioxidante e atividade antimicrobiana do extrato com maior característica antioxidante. Os extratos foram obtidos pelo método convencional e extração assistida por ultrassom, variando a temperatura $\left(20^{\circ} \mathrm{C}, 40^{\circ} \mathrm{C}\right.$ e $\left.60^{\circ} \mathrm{C}\right)$. Foram quantificados os fenólicos totais, flavonóides totais, a atividade antimicrobiana, e atividade antioxidante pelos métodos DPPH, FRAP, e ORAC. Os métodos de extração convencional e ultrassom influenciaram no teor de fenólicos em todas as temperaturas testadas. Os flavonóides não sofreram influência dos métodos de extração. $A$ atividade antioxidante (DPPH) foi superior no método ultrassom nas temperaturas de $40^{\circ} \mathrm{C}$ e $60^{\circ} \mathrm{C}$, entretanto pelo método FRAP os melhores resultados foram na extração convencional. Os métodos convencional e ultrassom não influenciaram no $I C_{50}$ nas temperaturas de $20^{\circ} \mathrm{C}$ e $40^{\circ} \mathrm{C}$, mas a atividade antioxidante pelo método ORAC sofreu influencia dos métodos em todas as temperaturas. O extrato obtido a $60^{\circ} \mathrm{C}$ pelo método ultrassom possui elevada ação antimicrobiana frente a cepas de Salmonella sp., Escherichia coli, e Staphylococcus aureus. A extração assistida por ultrassom pode ser considerada adequada para obtenção de extratos de marcela, que são ricos em compostos bioativos com alta atividade antioxidante.

Palavras-chave: ultrassom, compostos bioativos, antioxidantes naturais, Achyrocline satureioides.

\section{INTRODUCTION}

Marcela (Achyrocline satureioides) is a medicinal plant with a high polyphenolic compound content. The majority of these compounds are flavonoids and different phenolic acids such as caffeic and chlorogenic acids. Marcela is a herb used in Brazil, Argentina, Uruguay and Paraguay for its analgesic, antimicrobial, antispasmodic, anti- inflammatory and anti-tumor properties: it has high antioxidant potential (BLASINA et al., 2009).

According to ZHENG \& WANG (2001), there has been increasing interest in finding naturally occurring antioxidants for use in foods in order to replace synthetic antioxidants. Finding efficient extractive methods, as well as characterizing bioactive compounds from natural sources, are great challenges for researchers. 
Quality of extracts are influenced by factors such as the extraction methods that are used, the part of the plant material that is used, the origin of the extracts, the degree of processing, the particle size and the solvent used, as well as the extraction time, temperature, polarity and solvent concentration (TIWARI et al., 2011).

Ultrasonic extraction is a promising extractive technique because it promotes the exhaustive extraction of active plant principles with relatively small energy expenditure and reduced time, as well as greater safety in the process. According to ROCHA et al. (2009), the waves generated in ultrasonic extraction propagate in the liquid medium, causing pressure variations which are responsible for the creation and implosion of gas microbubbles in the center of a liquid. This high frequency forms shock waves at the moment of the implosion of the bubbles and also produces a vibratory effect in the plant cell, which is capable of causing it to rupture and release its contents.

Based on the above, the aim of this study was to evaluate the effect of extractive conditions on the bioactive compounds and antioxidant activity of marcela (Achyrocline satureioides), as well as determining antimicrobial activity of the best extract.

\section{MATERIALS AND METHODS}

The inflorescences of marcela were harvested in the month of April in the rural area of Santa Maria (RS), Brazil. The marcela was oven dried at $45^{\circ} \mathrm{C}( \pm 5)$ for 48 hours, minced in a Willy type mill, and passed through 20 mesh sieve. The material was stored in a freezer in polyethylene bags at $-18^{\circ} \mathrm{C}$ until the end of the analysis.

Hydroalcoholic extracts were prepared from $5 \mathrm{~g}$ of milled marcela with $50 \mathrm{ml}$ of $70 \%$ cereal alcohol at a ratio of 1:10 (w/v). The extraction time was set at 20 minutes in accordance with PIOVESAN et al. (2017). For the extraction by the conventional method, this mixture was kept in an ultra-thermostated bath (Marconi, model MA184, São Paulo, Brazil) and subjected to constant stirring using a stirrer (Marconi MA-039, Sao Paulo, Brazil) at temperature $20^{\circ} \mathrm{C}, 40^{\circ} \mathrm{C}$ and $60^{\circ} \mathrm{C}$. For the ultrasound extraction method, the cereal alcohol and the marcela were immersed in an ultrasound bath (QUIMIS ${ }^{\circledR}$, model Q335D, São Paulo, Brazil) operating at $40 \mathrm{kHz}$ frequency at temperature $20^{\circ} \mathrm{C}$, $40^{\circ} \mathrm{C}$ and $60^{\circ} \mathrm{C}$ (CAVALHEIRO, 2013). Extracts were subsequently centrifuged at $202 \mathrm{~g}$ for 10 minutes and filtered; the volume was adjusted to $50 \mathrm{~mL}$ and they were then packed in amber bottles and stored in a freezer $\left(-18^{\circ} \mathrm{C}\right)$ until analysis.

Determination of total phenolic compounds was performed by the Folin-Ciocalteu method, as described by ROESLER et al. (2007), which suggests incubating the tubes for 5 minutes in a $50^{\circ} \mathrm{C}$ water bath. For the quantification, a calibration curve was performed $\left(\mathrm{y}=0.0012 \mathrm{x}+0.021 \mathrm{R}^{2}=0.9953\right)$ using gallic acid in concentrations of $10-500 \mathrm{mg} . \mathrm{L}^{-1}$. The content of total phenolic compounds was expressed in milligrams of gallic acid/g of dry base marcela ( $\mathrm{mg} \mathrm{GAE}^{-1}$ ).

The total flavonoid content was determined by the method proposed by ZHISHEN et al. (1999). For the calculation, a calibration curve was performed $\left(\mathrm{y}=0.0027 \mathrm{x}-0.0772 \mathrm{R}^{2}=0.9672\right)$ using quercetin at concentrations of $25-200 \mathrm{mg} . \mathrm{L}^{-1}$. The total flavonoid content was expressed in $\mathrm{mg}$ equivalent of quercetin $/ \mathrm{g}$ of dry base marcela (mg EQ g $\left.{ }^{-1}\right)$.

The ferric reducing antioxidant potential (FRAP) test was determined according to the methodology described by BENZIE \& STRAIN (1996). The TEAC (trolox equivalent antioxidant capacity) (2.5 to $25 \mu \mathrm{M}$ range) was used for the calibration curve $\left(\mathrm{y}=0.0601 \mathrm{x}-0.0679 \mathrm{R}^{2}=0.9937\right)$. Results were expressed in $\mu \mathrm{mol}$ equivalents of trolox/g of dry base marcela ( $\mu \mathrm{mol}$ TEAC $\mathrm{g}^{-1}$ ).

The determination of the antioxidant activity by the DPPH (2,2-diphenyl-1-picrylhydrazyl) method was performed according to BRAND-WILLIANS et al. (1995). A quantity of $2.5 \mathrm{~mL}$ of a $0.1 \mathrm{mM}$ DPPH methanolic solution was incubated with $0.5 \mathrm{~mL}$ solutions containing increasing concentrations of the extracts for 30 minutes in the absence of light. The results were expressed as the radical scavenging activity percentage $(\%)$ of the $\mathrm{DPPH}$ radical according to the following formula:

$\% D P H H_{\text {radicalscavenging }}=\left[\left(A_{0}-A_{s}\right) \div \mathrm{A}_{0}\right] \times 100$

Where $\mathrm{A}_{0}$ is the absorbance of the control and As is the absorbance of the sample. Effective concentration had 50\% radical inhibition activity $\left(\mathrm{IC}_{50}\right)$, expressed as $\mathrm{mg}$ extract $/ \mathrm{mL}$, which was determined from the graph of the free radical scavenging activity (\%) against the extract concentration. A standard Trolox curve in $\mu$ mol was also constructed versus \% of inhibition, where the result was expressed in $\mu \mathrm{mol}$ equivalents of TEAC/g of sample dry ( $\mu$ mol TEAC $\left.\mathrm{g}^{-1}\right)$.

The oxygen radical absorption capacity (ORAC) was analyzed as proposed by DÁVALOS et al. (2004). Results were expressed in $\mu \mathrm{mol}$ equivalent of Trolox per gram of dry base marcela ( $\mu$ mol Trolox/g).

Evaluation of antimicrobial activity was performed according to a technique described by 
SOQUETTA et al. (2016), with modifications, where the extract obtained by ultrasound extraction at $60^{\circ} \mathrm{C}$ was used in the disk diffusion method, using three bacterial strains (Salmonella Enteritidis ATCC 13076, Escherichia coli ATCC 25922, and Staphylococcus aureus ATCC25923). Cultures obtained from suspensions in BHI broth, with densities adjusted to tube turbidity with 0.5 of the McFarland scale $\left(10^{8} \mathrm{UFC} / \mathrm{mL}\right)$, were seeded on the surface of plates containing Mueller-Hinton Agar medium. Filter paper disks (6mm diameter) soaked with $20 \mu \mathrm{l}$ of extract were placed on the medium. A disk with $30 \mu \mathrm{g}$ chloramphenicol was used for positive control and for negative control the paper disks were soaked in sterilized distilled water. Plates were incubated in an oven $\left(37^{\circ} \mathrm{C}\right)$ for 24 hours.

The extracts and the analyses were conducted in triplicate. Results were submitted to analysis of variance (ANOVA) and the means were compared to each other using Tukey's test at 5\% significance. Statistica ${ }^{\circledR} 7.0$ statistical software was used.

\section{RESULTS AND DISCUSSION}

Extracts obtained by the conventional method at $20^{\circ} \mathrm{C}$ and $60^{\circ} \mathrm{C}$ showed higher phenolic contents compared to the temperature of $40^{\circ} \mathrm{C}$. In relation to flavonoids, the increase in temperature did not have an influence. In contrast, MIGLIATO (2011) investigated the influence of temperature on the extraction of flavonoids from leaves of Syzygium cumini (L.) Skeels and observed that increased temperature significantly affected the extraction of flavonoids. In the present study, for the ultrasound method, the extract obtained at $60^{\circ} \mathrm{C}$ showed the highest phenolic content. In relation to flavonoids, increased temperature had a positive influence. In another study, GUERRA et al. (2016) verified that the optimum operating condition for obtaining phenolic compounds in Tommy atkins bark is at a temperature of $60^{\circ} \mathrm{C}$. TABARAKI et al. (2012) also reported that temperature influenced the extraction process; heat makes the cell wall more permeable, increasing the solubility of the compounds and the diffusion coefficient of the solvent.

In the present study, comparing the two methods of extraction it can be seen that the extracts obtained at all the temperatures showed significant difference in phenolic content, and that the highest results were obtained in the extraction by ultrasound, i.e. the method influenced these temperatures. SILVA et al. (2016) corroborated that with the ultrasonic extraction of the bark of Litchi Chinensis Sonn significantly increased the total phenolic compounds and iron reducing compounds, in addition to obtaining the lowest value for the inhibitory capacity of the extract.

Different techniques are used to determine in vitro antioxidant activity in order to allow the selection of pure substances and matrices with this property. In the present study, the antioxidant activities of marcela extracts were evaluated by the following methods: DPPH, FRAP and ORAC. Table 1 showed that in the extraction using ultrasound at $60^{\circ} \mathrm{C}$ the $\mathrm{IC}_{50}$ of the extract was lowest, consequently, the increase in temperature increased the antioxidant activity. The antioxidant activity measured by FRAP using the conventional method was not influenced at temperatures of $20^{\circ} \mathrm{C}$ and $40^{\circ} \mathrm{C}$ but there was an increase in the activity at $60^{\circ} \mathrm{C}$. However, using the ORAC method the temperature that favored extraction was $20^{\circ} \mathrm{C}$. Analyzing the ultrasound method at different temperatures it can be seen that this method did not influence the $\mathrm{IC}_{50}$ at temperatures of $20^{\circ} \mathrm{C}$ and $40^{\circ} \mathrm{C}$, while the temperature of $60^{\circ} \mathrm{C}$ resulted in the lowest value and, consequently, the highest antioxidant activity. In terms of the FRAP method, increased temperature did not influence the antioxidant activity. Ultrasonic extraction method positively influenced the antioxidant activity by ORAC at $40^{\circ} \mathrm{C}$ and $60^{\circ} \mathrm{C}$, differing statistically from the temperature of $20^{\circ} \mathrm{C}$.

In terms of $\mathrm{IC}_{50}$ it was reported that the ultrasound method differed significantly at a temperature of $60^{\circ} \mathrm{C}$ from the conventional method, presenting higher antioxidant activity; however, at the other temperatures the methods did not differ. Analyzing antioxidant activity by FRAP, the conventional extraction method was better than ultrasound at all the tested temperatures, as well as in the antioxidant method of $\mathrm{IC}_{50}$, where there was only statistical difference at a temperature of $60^{\circ} \mathrm{C}$. According to GUIMARÃES et al. (2011), there may be variation in antioxidant activity, depending on the compound and the concentration that is used for each methodology. In this case, the ultrasound method probably extracted more compounds, which facilitates the donation of hydrogen by these compounds to neutralize the DPPH radical. Determination by the FRAP method depends on the redox potential of the compounds extracted in the extract, which are characterized by the complexity of their molecules. The compounds extracted with hydroalcoholic solution probably have redox potential to be quantified by this method (PULIDO et al., 2000).

The ORAC method showed that at temperatures of $40^{\circ} \mathrm{C}$ and $60^{\circ} \mathrm{C}$ the ultrasound method was better, presenting higher antioxidant 
Table 1 - Total phenolics, total flavonoids, inhibitory capacity $\left(\mathrm{IC}_{50}\right)$, iron reduction capacity (FRAP) and oxygen radical absorption capacity (ORAC), of extracts obtained by different extraction methods and at different temperatures.

\begin{tabular}{|c|c|c|}
\hline \multirow{2}{*}{ Temperature $\left({ }^{\circ} \mathrm{C}\right)$} & Conventional method & Ultrasound method \\
\hline & \multicolumn{2}{|c|}{ 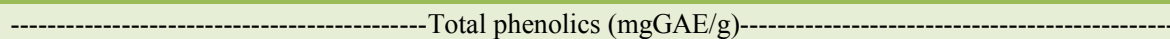 } \\
\hline $20^{\circ} \mathrm{C}$ & $313.05^{\mathrm{Ba}} \pm 1.63$ & $299.28^{\mathrm{Cb}} \pm 0.81$ \\
\hline $40^{\circ} \mathrm{C}$ & $246.15^{\mathrm{Ab}} \pm 2.61$ & $315.48^{\mathrm{Ba}} \pm 2.45$ \\
\hline $60^{\circ} \mathrm{C}$ & $312.30^{\mathrm{Bb}} \pm 2.37$ & $346.62^{\mathrm{Aa}} \pm 0.32$ \\
\hline \multicolumn{3}{|c|}{ 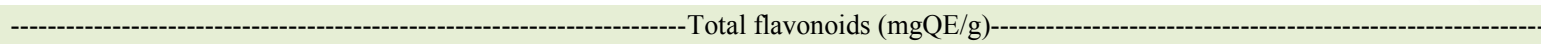 } \\
\hline $20^{\circ} \mathrm{C}$ & $21.53^{\mathrm{Aa}} \pm 2.93$ & $17.28^{\mathrm{Ca}} \pm 0.48$ \\
\hline $40^{\circ} \mathrm{C}$ & $19.72^{\mathrm{Aa}} \pm 0.82$ & $19.90^{\mathrm{Ba}} \pm 0.54$ \\
\hline $60^{\circ} \mathrm{C}$ & $20.35^{\mathrm{Aa}} \pm 1.31$ & $21.50^{\mathrm{Aa}} \pm 0.39$ \\
\hline \multicolumn{3}{|c|}{ 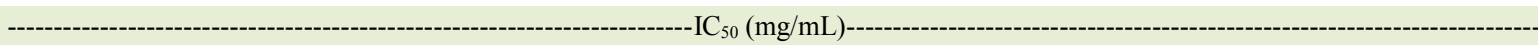 } \\
\hline $20^{\circ} \mathrm{C}$ & $0.37^{\mathrm{Aa}} \pm 0.08$ & $0.48^{\mathrm{Aa}} \pm 0.04$ \\
\hline $40^{\circ} \mathrm{C}$ & $0.42^{\mathrm{Aa}} \pm 0.05$ & $0.46^{\mathrm{Aa}} \pm 0.03$ \\
\hline $60^{\circ} \mathrm{C}$ & $0.45^{\mathrm{Aa}} \pm 0.03$ & $0.28^{\mathrm{Bb}} \pm 0.06$ \\
\hline \multicolumn{3}{|c|}{-1 } \\
\hline $20^{\circ} \mathrm{C}$ & $13.11^{\mathrm{Ba}} \pm 1.81$ & $9.46^{\mathrm{Ab}} \pm 1.46$ \\
\hline $40^{\circ} \mathrm{C}$ & $14.22^{\mathrm{Ba}} \pm 1.87$ & $9.29^{\mathrm{Ab}} \pm 2.47$ \\
\hline $60^{\circ} \mathrm{C}$ & $18.85^{\mathrm{Aa}} \pm 2.94$ & $11.40^{\mathrm{Ab}} \pm 0.38$ \\
\hline \multicolumn{3}{|c|}{ 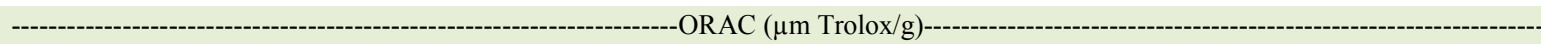 } \\
\hline $20^{\circ} \mathrm{C}$ & $1042.75^{\mathrm{Aa}} \pm 5.72$ & $866.90^{\mathrm{Bb}} \pm 3.67$ \\
\hline $40^{\circ} \mathrm{C}$ & $882.65^{\mathrm{Cb}} \pm 1.62$ & $1057.25^{\mathrm{Aa}} \pm 4.73$ \\
\hline $60^{\circ} \mathrm{C}$ & $1005.17^{\mathrm{Bb}} \pm 1.85$ & $1060.10^{\mathrm{Aa}} \pm 7.6$ \\
\hline
\end{tabular}

Results are expressed as Mean $\pm \mathrm{SD}(\mathrm{n}=9)$. GAE $=$ Gallic acid equivalent; QE: Quercetin equivalent. TEAC $=$ trolox equivalent antioxidan1 capacity. ${ }^{\mathrm{A}, \mathrm{B}}$ Equivalent capital letters in the same column did not present significant differences by Tukey's test ( $\mathrm{p}>0.05$ ) in the same extraction method between the different tested temperatures. ${ }^{\mathrm{a}, \mathrm{b}}$ Equal lowercase letters on the same line do not show significant difference between the same temperatures for the different extraction methods.

activity, in the same way for the DPPH method (Figure 1), ultrasonic extraction was also higher at these temperatures, coinciding with the lower $\mathrm{IC}_{50}$ at $60^{\circ} \mathrm{C}$. In the conventional extraction for $\mathrm{IC}_{50}$ there was no significant difference between the temperatures tested, since for antioxidant activity by the DPPH method there was no statistical difference in the temperatures of $20^{\circ} \mathrm{C}$ and $60^{\circ} \mathrm{C}$.

The marcela extracts showed inhibition in relation to all the evaluated strains, Salmonella sp.

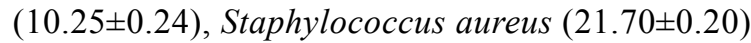
and Escherichia coli (13.40 \pm 0.15$)$. According to MOTHANA \& LINDEQUIST (2005), inhibition halos that are $8-13 \mathrm{~mm}$ in size reflect extracts with moderately active action power, since inhibition halos $>14 \mathrm{~mm}$ in size represent very active extracts. Considering that the size of the halos in the marcela extracts were $10-21 \mathrm{~mm}$, the marcela extracts were very active in relation to the strains of Staphylococcus aureus and Escherichia coli, and moderately active in relation to Salmonella $s p$. According to SOUZA et al. (2002), the results of the present study suggested that the chemical components of this plant were responsible for this action in relation to the bacteria that were analyzed, i.e. the flavonoids, quercetin, 3-O-methylquercetin and luteolin.

\section{CONCLUSION}

Ultrasonic assisted extraction was efficient to obtain extracts of marcela which are rich in bioactive compounds with high antioxidant activity. Results also demonstrated that the temperature of $60^{\circ} \mathrm{C}$ presented higher amount of extracted compounds. The marcela presented antimicrobial action in relation to strains of Salmonella sp., Escherichia coli, and Staphylococcus aureus. Due to its low cost and its widespread availability, marcela can be considered a promising natural source of extracts that are rich in antioxidant compounds and can be used to replace synthetic antioxidants in the food industry and ultrasonic assisted extraction an adequate and efficient technique to obtain these compounds. 


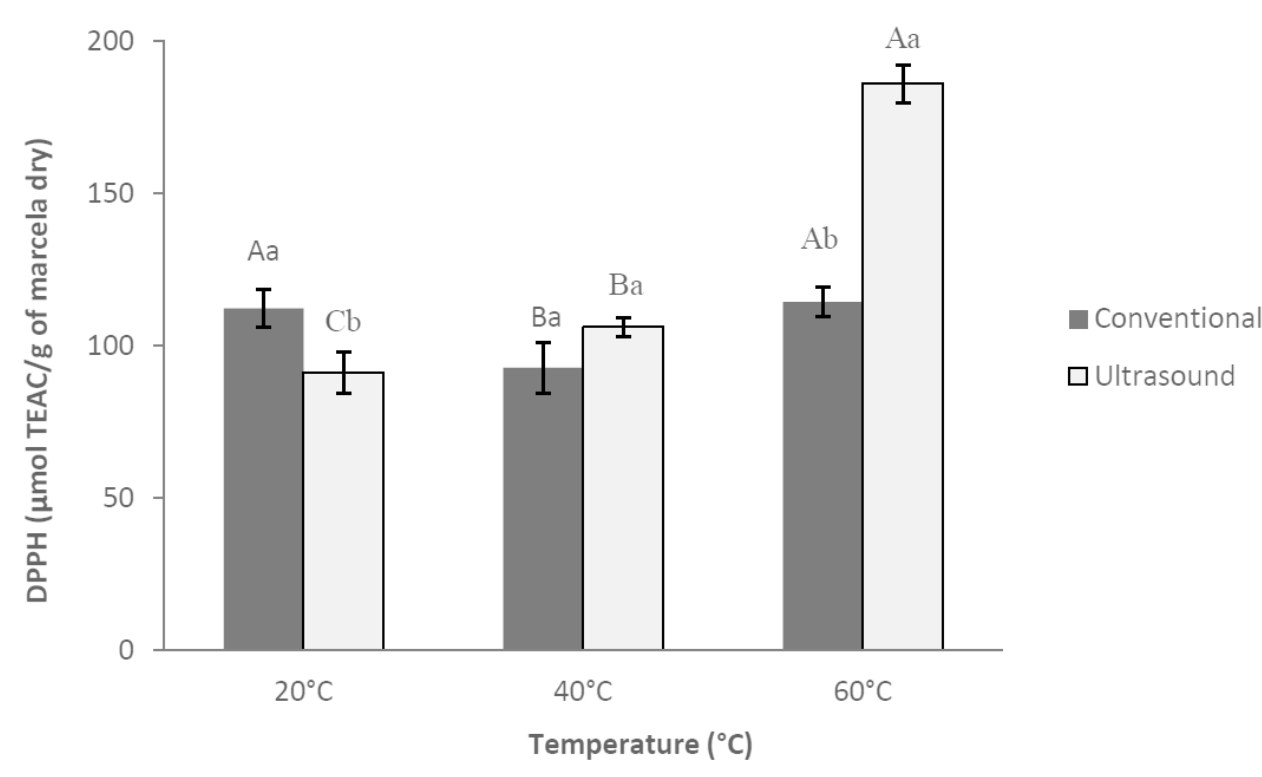

Results are expressed as Mean $\pm \mathrm{SD}(\mathrm{n}=9)$

${ }^{\mathrm{A}, \mathrm{B}}$ Equivalent capital letters in the same column did not present significant differences by Tukey's test $(\mathrm{p}>0.05)$ in the same extraction method between the different tested temperatures. ${ }^{\mathrm{a}, \mathrm{b}}$ Equal lowercase letters on the same line do not show significant difference between the same temperatures for the different extraction methods.

Figure 1 - Antioxidant activity determined by the free radical capture method (DPPH) of the marcela extracts obtained by different methods and at different extraction temperatures.

\section{ACKNOWLEDGEMENTS}

The authors wish to thank the Coordenação de Aperfeiçoamento de Pessoal de Nível Superior (CAPES) for granting a master's degree scholarship to the first-named author and to the Department of Science and Technology in Food of the Universidade Federal de Santa Maria, RS, Brazil.

\section{DECLARATION OF CONFLICTING INTERESTS}

The authors declare no conflict of interest. The founding sponsors had no role in the design of the study; in the collection, analyses, or interpretation of data; in the writing of the manuscript, and in the decision to publish the results.

\section{REFERENCES}

BENZIE, I.F.F.; STRAIN, J.J. The ferric reducing ability of plasma (FRAP) as a measure of "antioxidant power": the frap assay. Analytical Biochemistry, v.239, p.70-76, 1996. Available from: $<$ https://doi.org/10.1006/ abio.1996.0292>. Accessed: Jun. 20, 2017. doi: 10.1006/abio.1996.0292.

BLASINA, M.F. et al. Differentiation induced by Achyrocline satureioides (Lam) infusion in Pc 12 cells. Phytother Research. v.23, n.9, p. 1263-1269, 2009. Available from: <http://dx.doi.org/10.1002/ ptr.2607>. Accessed: Jun. 05, 2017. doi: 10.1002/ptr.2607.

BRAND-WILLIANS, W. et al. Use of a free radical method to evaluate antioxidant activity. Food Science and Technology, v. 28, p. 25-30, 1995. Available from: <https://doi.org/10.1016/S00236438(95)80008-5>. Accessed: Jun. 20, 2017. doi: 10.1016/S00236438(95)80008-5.

CAVALHEIRO, C.V. Extração de compostos fenólicos assistida por ultrassom e determinação de ácidos graxos e minerais em folhas de Olea europaea L. 2013. 93f. Dissertação (Mestrado em Ciência e Tecnologia do Alimentos) - Curso de Pós-graduação em Ciência e Tecnologia dos Alimentos. Universidade Federal de Santa Maria.

CORBIN, C. et al. Development and validation of an efficient ultrasound assisted extraction of phenolic compounds from flax (Linum usitatissimum L.) seeds. Ultrasonics Sonochemistry v. 26, p. 176-185, 2015. Available from: $<$ https://doi.org/10.1016/j. ultsonch.2015.02.008>. Accessed: Aug. 11, 2017. doi: 10.1016/j. ultsonch.2015.02.008.

DÁVALOS, A. et al. Extending applicability of the Oxygen Radical Absorbance Capacity (ORAC- Fluorescein) Assay. Journal of Agricultural and Food Chemistry, v. 52 p. 48-54, 2004. Available from: $<$ http://dx.doi.org/10.1021/jf0305231>. Accessed: Jun. 10, 2017. doi: 10.1021/jf0305231. 
GUERRA, A.P. et al. Otimização da extração de compostos fenólicos da casca de manga (Tommy atkins) utilizando processo assistido por ultrassom. E-xacta, v. 9, n.1, p.103-110, 2016. Available from: <http:// doi.org/10.18674/exacta.v9i1.1783>. Accessed: Mar. 14, 2018. doi: 10.18674/exacta.v9i1.1783.

GUIMARÃES, L. et al. Atividades antioxidante e fungitóxica do óleo essencial de capim-limão e do citral. Revista Ciência Agronômica, v. 42, n.2, p. 464-472, 2011. Available from: <http://dx.doi.org/10.1590/ S1806-66902011000200028>. Accessed: Jun. 09, 2017. doi: 10.1590/ S1806-66902011000200028.

MIGLIATO, K.F. et al. Factorial design of the optimization extraction of Syzygium cumini (L.) Skeels fruits. Química Nova, v.34, n.4, p.695-699, 2011. Available from: $<$ http://dx.doi.org/10.1590/S010040422011000400024>. Accessed: Jun. 10, 2017. doi: 10.1590/ S0100-40422011000400024.

MOTHANA, R.A.A.; LINDEQUIST, U. Antimicrobial activity of some medicinal plants of the island Soqotra. Journal of Ethnopharmacology Etnopharmacology, v. 96, p. 177-181, 2005. Available from: $<$ https://doi.org/10.1016/j.jep.2004.09.006>. Accessed: Jul. 27, 2017. doi: 10.1016/j.jep.2004.09.006.

PIOVESAN, N. et al. Microwave-assisted extraction of bioactive compounds from blueberry (Vaccinium ashei Reade) and their antioxidant and antimicrobial capacity. International Food Research Journal, v. 24, n.6, p.2526-2533, 2017.

PULIDO, R. et al. Antioxidant activity of dietary polyphenolics as determined by a modified ferric reducing/antioxidant power assay. Journal of the Agricultural and Food Chemistry, v.48, n.8, p.3963402, 2000. Available from: <https://doi.org/10.1021/jf9913458>. Accessed: Jun. 09, 2017. doi: 10.1021/jf9913458.

ROCHA, L. G. et al. Evaluation of the leishmanicide action of ethanol extracts of Crotalaria retusa L. (Fabaceae). Revista Brasileira Farmacognosia, v.19, p.51-56, 2009. Available from: <https://doi. org/10.1590/S0102-695X2009000100012>. Accessed: Jun. 23, 2017. doi: 10.1590/S0102-695X2009000100012.

ROESLER, R. et al. Antioxidant activity of cerrado fruits. Science and Food Technology, v.27, p.53-60, 2007. Available from:
<10.1590/S0101-20612007000100010>. Accessed: Jun. 05, 2017. doi: 10.1590/S0101-20612007000100010.

SILVA, C. et al. Extração Assistida por Ultrassom de Compostos Bioativos das Cascas de Lichia (Litchi Chinensis Sonn.). Revista Ciências Exatas e Naturais, v.18, n.1, p.81-96, 2016. Available from: <http://doi.org/10.5935/RECEN.2016.01.07>. Accessed: Mar. 21, 2018. doi: 10.5935/RECEN.2016.01.07.

SOQUETTA, M.B. et al. Characterization of physiochemical and microbiological properties, and bioactive compounds, of flour made from the skin and bagasse of kiwi fruit (Actinidia deliciosa). Food Chemistry, v.199, p.471-478, 2016. Available from: <https://doi. org/10.1016/j.foodchem.2015.12.022>. Accessed: Jun. 29, 2017. doi: 10.1016/j.foodchem.2015.12.022.

SOUZA, K.C.B. et al. LC determination of flavonoids: separation of quercetin, luteolin and 3-O -methylquercetin in Achyrocline satureioides preparations. Journal of Pharmaceutical and Biomedical Analysis, v.28, p.771-777, 2002. Available from: $<$ https://doi.org/10.1016/S07317085(01)00693-8>. Accessed: Jun. 04, 2017. doi: 10.1016/S07317085(01)00693-8.

TABARAKI, R. et al. Optimization of ultrasonic-assisted extraction of pomegranate (Punicagranatum L.) peel antioxidants by response surface methodology. Separation and Purification Technology, v.98, p.16-23, 2012. Available from: <https://doi. org/10.1016/j.seppur.2012.06.038>. Accessed: Jun. 29, 2017. doi: 10.1016/j.seppur.2012.06.038.

TIWARI, P. et al. Phytochemical screening and Extraction: A Review. Internationale Pharmaceutica Sciencia, v.1, p.98-106, 2011.

ZHENG, W.; WANG, S. Y. Antioxidant activity and phenolic compounds in selected herbs. Journal of Agricultural and Food Chemistry, v.9, p.5165- 5170, 2001. Available from: $<$ http://doi.org/10.1021/jf010697n>. Accessed: Out. 08, 2017. doi: 10.1021/jf010697n.

ZHISHEN, J. et al. The determination of flavonoid contents in mulberry and their scavenging effects on superoxide radicals. Food Chemistry, v.64, p.555-559, 1999. Available from: <http://doi. org/10.1016/S0308-8146(98)00102-2>. Accessed: Out. 12, 2017. doi: 10.1016/S0308-8146(98)00102-2. 